\title{
IL-17 and IFN- $\gamma$ expression in lymphocytes from patients with active tuberculosis correlates with the severity of the disease
}

\author{
Javier O. Jurado,* Virginia Pasquinelli, * Ivana B. Alvarez,* Delfina Peña, * Ana I. Rovetta,* \\ Nancy L. Tateosian, ${ }^{\dagger}$ Horacio E. Romeo, ${ }^{\ddagger}$ Rosa M. Musella, ${ }^{\S}$ Domingo Palmero, ${ }^{\S}$ \\ H. Eduardo Chuluyán, ${ }^{\dagger}$ and Verónica E. García*,1 \\ *Department of Biological Chemistry, University of Buenos Aires, School of Sciences, ${ }^{\dagger}$ Department of Pharmacology, University \\ of Buenos Aires School of Medicine, Buenos Aires, Argentina; ${ }^{\ddagger}$ Pontificia Universidad Católica Argentina, Facultad de Ciencias \\ Médicas, PIB-CONICET, Buenos Aires, Argentina; and ${ }^{\S}$ División de Tisioneumonología, Hospital F. J. Muñiz, Buenos Aires, \\ Argentina
}

RECEIVED DECEMBER 14, 2011; REVISED FEBRUARY 8, 2012; ACCEPTED FEBRUARY 18, 2012. DOI: 10.1189/jlb.1211619

\begin{abstract}
Th1 lymphocytes are crucial in the immune response against Mycobacterium tuberculosis. Nevertheless, IFN- $\gamma$ alone is not sufficient in the complete eradication of the bacteria, suggesting that other cytokines might be required for pathogen removal. Th17 cells have been associated with $M$. tuberculosis infection, but the role of IL-17-producing cells in human TB remains to be understood. Therefore, we investigated the induction and regulation of IFN- $\gamma$ and IL-17 during the active disease. TB patients were classified as High and Low Responder individuals according to their $\mathrm{T}$ cell responses against the antigen, and cytokine expression upon $M$. tuberculosis stimulation was investigated in peripheral blood and pleural fluid. Afterwards, the potential correlation among the proportions of cytokine-producing cells and clinical parameters was analyzed. In TB patients, $M$. tuberculosis induced IFN- $\gamma$ and IL-17, but in comparison with BCG-vaccinated healthy donors, IFN- $\gamma$ results were reduced significantly, and IL-17 was markedly augmented. Moreover, the main source of IL-17 was represented by $\mathrm{CD} 4^{+} \mathrm{IFN}-\gamma^{+} \mathrm{IL}-17^{+}$Iymphocytes, a Th1/Th17 subset regulated by IFN $-\gamma$. Interestingly, the ratio of antigen-expanded CD4 ${ }^{+}$IFN- $\gamma^{+}$IL-17 ${ }^{+}$Iymphocytes, in peripheral blood and pleural fluid from TB patients, was correlated directly with clinical parameters associated with disease severity. Indeed, the highest proportion of CD4 ${ }^{+}$IFN- $\gamma^{+}$IL-17 ${ }^{+}$cells was detected in Low Responder TB patients, individuals displaying se-
\end{abstract}

\footnotetext{
Abbreviations: AFB=acid-fast bacilli, BCG=bacillus Calmette-Guérin, $\mathrm{HD}=$ healthy donors, $H R=$ high-responder tuberculosis patients, lo=ionomycin, LR=low-responder tuberculosis patients, Mtb-Ag= Mycobacterium tuberculosis antigen, PD-1=programmed cell death-1, PFMCs=pleural fluid mononuclear cells, $\mathrm{RORC} / \gamma \top=$ retinoic acid receptorrelated orphan receptor $\mathrm{C} / \gamma \mathrm{T}$, SLAM=signaling Iymphocytic activation molecule, $\mathrm{T}$-bet=T-box-containing protein expressed in T cells, $\mathrm{TB}=$ tuberculosis
}

The online version of this paper, found at muw.jleukbio.org, includes supplemental information. vere pulmonary lesions, and longest length of disease evolution. Taken together, the present findings suggest that analysis of the expansion of CD4 ${ }^{+} \mathrm{IFN}-\gamma^{+} \mathrm{IL}-17^{+} \mathrm{T}$ lymphocytes in peripheral blood of TB patients might be used as an indicator of the clinical outcome in active TB. J. Leukoc. Biol. 91: 991-1002; 2012.

\section{Introduction}

The immune response elicited after $M$. tuberculosis infection is critically dependent on $\mathrm{CD} 4^{+} \mathrm{T}$ cells. In particular, Th1 cells have been shown to play an important role in granuloma formation and clearance of $M$. tuberculosis infection [1-3]. In fact, deficiencies in the IL-12-IFN- $\gamma$-STAT1 signaling pathway lead to the dissemination of mycobacterial infections $[4,5]$. However, the fact of how M. tuberculosis is able to evade host immune surveillance and persist, particularly inside macrophages, remains to be understood. It has been proposed that $\mathrm{CD}^{+}{ }^{+} \mathrm{T}$ cells producing IL-17 and IL-22 might contribute to adaptive immunity to $M$. tuberculosis [6]. Indeed, early cellular responses to $M$. tuberculosis induce IL-17 production, contributing to granuloma formation and control of bacterial growth [7]. Nevertheless, excessive IL-17 levels exacerbated inflammation, increasing neutrophil recruitment and tissue damage [8]. Despite the great strides made in the characterization of the acquired cellular response in TB patients, it remains to be elucidated what exactly constitutes a protective response [7].

During the chronic phase of TB, an equilibrium between Th1 and Th17 responses needs be accomplished to control bacterial growth and constrain immunopathology [9]. Accordingly, the balance between IL-23/IL-17 and IL-12/IFN- $\gamma$ pathways might define the resolution of $M$. tuberculosis infection [10], making such equilibrium crucial for the definition of the

1. Correspondence: Department of Biological Chemistry, University of Buenos Aires, School of Sciences, Intendente Güiraldes 2160, Pabellón II, 4th Floor, Capital Federal, 1428, Buenos Aires, Argentina. E-mail: vgarcia@ qb.fcen.uba.ar 
disease outcome [9]. Nevertheless, although the role of IFN- $\gamma$ in the defense against M. tuberculosis and its ability to inhibit IL-17 production have been addressed [11, 12], the participation of IL-17-producing cells during human M. tuberculosis infection remains controversial. In the present report, we investigated the role of IL-17-secreting cells and their relationship with IFN- $\gamma$-expressing lymphocytes in patients with TB. Furthermore, we analyzed the potential correlation between the proportion of cytokine expression in peripheral blood and pleural fluid lymphocytes and the severity of the disease.

\section{MATERIALS AND METHODS}

\section{Patients}

HIV-uninfected patients with active TB were evaluated at the Hospital Muñiz (Buenos Aires, Argentina). Diagnosis of disease was established based on clinical and radiological data, together with the identification of AFB in sputum. Patients included in this study had received less than 1 week of anti-TB therapy. In some cases, tuberculous pleural effusions were obtained by thoracentesis. TB patients were classified as reported previously [13], based on in vitro lymphocyte responses to $M t b$-Ag. Briefly, High Responder (HR) patients are individuals displaying significant proliferative responses, IFN- $\gamma$ production, and an increased SLAM expression against the antigen, whereas Low Responder (LR) patients exhibit low proliferative responses, IFN- $\gamma$ secretion, and percentages of SLAM ${ }^{+}$cells [13]. Healthy donors (HD), who had received BCG vaccination at birth and lacked a history of TB, participated in the study, excluding those subjects with latent TB (determined by Quantiferon TB Gold test, Cellestis, Valencia, CA, USA). The control group included individuals who were matched in terms of sex, age, and ethnicity with TB patients included in the study. All participants provided a written, informed consent for the collection of samples and subsequent analysis. The protocols conducted in this work were approved by the Ethical Committee of the Hospital Muñiz and by the International Review Board Fundación Huésped.

\section{Antigen}

In vitro stimulation of cells throughout the study was performed with a cell lysate from the virulent $M$. tuberculosis H37Rv strain prepared by probe sonication $(M t b-\mathrm{Ag})$, obtained through the NIH Biodefense and Emerging Infections Research Resources Repository, National Institute of Allergy and Infectious Diseases (Bethesda, MD, USA): M. tuberculosis, Strain H37Rv, whole cell lysate, NR-14822.

\section{Cell preparation and reagents}

PBMCs or PFMCs were isolated by centrifugation over Ficoll-Hypaque (Amersham Biosciences, Piscataway, NJ, USA) and cultured $\left(1 \times 10^{6}\right.$ cells $\left./ \mathrm{ml}\right)$ with/without Mtb-Ag $(10 \mu \mathrm{g} / \mathrm{ml})$ with RPMI 1640 (Gibco, Gaithersburg, MD, USA), supplemented with L-glutamine, gentamicin, and $10 \%$ human serum (Sigma-Aldrich, St. Louis, MO, USA), during 16 h, 48 h, or 5 days. In different experiments, cells were incubated with/without blocking anti-PD-1 mAb $(5 \mu \mathrm{g} / \mathrm{ml}$, J116, eBioscience, San Diego, CA, USA); agonistic anti-SLAM mAb (10 $\mu \mathrm{g} / \mathrm{ml}, \mathrm{A1} 2$, eBioscience); blocking IFN- $\gamma \mathrm{mAb}(10 \mu \mathrm{g} / \mathrm{ml}$, NIB42, eBioscience); or isotype controls, in the presence/absence of $M t b-\mathrm{Ag}$ (during 5 days) or PMA $(25 \mathrm{ng} / \mathrm{ml})$ plus Io $(10 \mu \mathrm{g} /$ $\mathrm{ml}$; for $16 \mathrm{~h}$ ). Then, IL-17A and IFN- $\gamma$ expression was determined by ELISA (eBioscience) and flow cytometry.

\section{Flow cytometry}

PBMCs or PFMCs were stimulated with $M t b$-Ag for 5 days and incubated with Golgi Stop reagent containing monensin $(1 \mu \mathrm{l} / \mathrm{ml}$; BD Biosciences, San Diego, CA, USA) for the final $5 \mathrm{~h}$ of culture.

Cells were then stained with specific fluorophore-marked antibodies against CD4 (PerCPCy5.5, OKT4, eBioscience), CD45RO (PECy7, UCHL1, Becton Dickinson, Franklin Lakes, NJ, USA), CCR7 (PE, 3D12, Becton
Dickinson), SLAM (PE, A12, Becton Dickinson), and/or PD-1 (FITC, MIH4, eBioscience). Intracellular staining was performed to determine IL17A (PE or Alexa Fluor 647, eBio64CAP17, eBioscience), IFN- $\gamma$ (FITC or allophycocyanin, 4S.B3, Becton Dickinson), T-bet (PE, eBio4B10, eBioscience), and RORC (PE, AFKJS-9, eBioscience) expression. For cytokine staining, BD Cytofix/Cytoperm and BD Perm/Wash buffers were used following the manufacturer's instructions. Forkhead box p3 fixation/permeabilization buffers (eBioscience) were used when staining of transcription factors (T-bet and RORC) was performed. Negative control samples were incubated with irrelevant isotype-matched mAb in parallel with experimental samples, which were analyzed on a FACSAria II flow cytometer (BD Biosciences).

\section{Statistical analysis}

The Mann-Whitney and the Wilcoxon rank sum tests were used to analyze differences between unpaired or paired samples, respectively. Fisher's exact test and $\chi^{2}$ for trend test were used for categorical variables. Correlation analyses were performed using the nonparametric Spearman correlation test. One-way ANOVA was used to compare the differences among multiple groups. Values of $P<0.05$ were considered significant.

\section{RESULTS}

\section{Patient population}

No differences regarding age distribution, sex, ethnicity, AFB in sputum, or frequency of extra pulmonary forms of TB were found in HR and LR TB patients (Table 1). However, significant differences were detected regarding X-ray radiography severity [14], leukocyte count, and time of disease evolution (days previous to hospital admission, during which, the patient displays clinical symptoms; Table 1). In particular, a pattern of considerable severity was detected in LR patients, who presented significant lower leukocytes, lymphocytes, and monocytes counts, evidenced severe pulmonary lesions, and had been ill longer than HR individuals (Table 1).

\section{M. tuberculosis promoted IL-17 secretion from CD4 ${ }^{+}$IFN- $\gamma^{+}$IL $-17^{+}$cells}

PBMCs from TB patients and HD were stimulated with $M t b-\mathrm{Ag}$ and IL-17, and IFN- $\gamma$ expression was analyzed. A significant increase in the levels of both cytokines was detected at 5 days (Fig. 1A). Among TB patients, both groups of individuals secreted similar amounts of IL-17, whereas antigen stimulation induced significantly lower production of IL-17 in HD (Fig. 1A). In fact, $M$. tuberculosis induced IFN- $\gamma$ and IL-17 in TB patients, but when compared with BCG-vaccinated HD, IFN- $\gamma$ was reduced significantly, whereas IL-17 was markedly augmented in patients bearing active $\mathrm{TB}$, indicating that the pattern of IL-17 secretion against $M t b-\mathrm{Ag}$ would be opposite to the pattern of IFN- $\gamma$ produced by the same individuals.

We next evaluated the potential relationship between IFN- $\gamma$ and IL-17 in TB by analyzing the coexpression of both cytokines. Surprisingly, the majority IL-17-producing cells expanded by $M t b-A g$ was IFN- $\gamma^{+}$(Fig. 1B). In contrast, PMA/Io treatment markedly expanded $\mathrm{CD} 4^{+} \mathrm{IFN}-\gamma^{+} \mathrm{IL}-17^{-}$and $\mathrm{CD} 4^{+} \mathrm{IFN}-\gamma^{-} \mathrm{IL}-17^{+}$lymphocytes, whereas it did not increase $\mathrm{CD} 4^{+} \mathrm{IFN}-\gamma^{+} \mathrm{IL}_{-1} 7^{+}$cells (Fig. 1C). Given that $\mathrm{CD} 4^{+} \mathrm{IFN}-\gamma^{+} \mathrm{IL}-$ $17^{+}$cells, expanded by $M t b$-Ag, coexpressed RORC and T-bet (Supplemental Fig. 1), present data demonstrated that the 
TABLE 1. Epidemiological and Demographic Characteristics of TB Patients

\begin{tabular}{|c|c|c|c|}
\hline Characteristic & $\begin{array}{l}\text { HR TB patients } \\
\quad(n=49)\end{array}$ & $\begin{array}{l}\text { LR TB patients } \\
\quad(n=32)\end{array}$ & $P$ value \\
\hline Proliferative responses (proliferation index) & $10.96 \pm 10$ & $2.31 \pm 0.37$ & $0.009^{\mathrm{a}}$ \\
\hline IFN- $\gamma$ production (fold-stimulation) & $231.1 \pm 51.60$ & $29.63 \pm 4.82$ & $0.0001^{\mathrm{a}}$ \\
\hline Increase in the percentage of SLAM-positive cells & $11.21 \pm 2.17$ & $3.97 \pm 1.11$ & $0.0093^{\mathrm{a}}$ \\
\hline Age & $32.1 \pm 3.5$ & $33.2 \pm 4.2$ & $0.9669^{\mathrm{b}}$ \\
\hline \multicolumn{4}{|l|}{ Sex } \\
\hline Male & $40(81.6 \%)$ & $26(81.25 \%)$ & \\
\hline Female & $9(18.4 \%)$ & $7(18.75 \%)$ & $0.7819^{c}$ \\
\hline \multicolumn{4}{|l|}{ Ethnicity } \\
\hline White (from European lineages) & $13(26.5 \%)$ & $7(21.9 \%)$ & \\
\hline American Indian & $36(73.5 \%)$ & $25(78.1 \%)$ & $0.7933^{\mathrm{c}}$ \\
\hline \multicolumn{4}{|l|}{ Hematologic studies } \\
\hline Leukocytes $\left(\right.$ cells $\left./ \mathrm{mm}^{3}\right)$ & $10746 \pm 488$ & $8394 \pm 432$ & $0.0025^{\mathrm{b}, \mathrm{d}}$ \\
\hline Lymphocytes (cells $/ \mathrm{mm}^{3}$ ) & $1870 \pm 103$ & $1410 \pm 115$ & $0.0049^{\mathrm{b}, \mathrm{d}}$ \\
\hline Monocytes $\left(\right.$ cells $\left./ \mathrm{mm}^{3}\right)$ & $997 \pm 55$ & $673 \pm 58$ & $0.0002^{\mathrm{b}, \mathrm{e}}$ \\
\hline \multicolumn{4}{|l|}{ AFB in sputum smear } \\
\hline Positive & $44(89.8 \%)$ & $28(87.5 \%)$ & \\
\hline Negative & $5(10.2 \%)$ & $4(12.5 \%)$ & $0.7341^{\mathrm{c}}$ \\
\hline \multicolumn{4}{|l|}{ Radiological lesions } \\
\hline Severe & $13(26.5 \%)$ & $18(56.3 \%)$ & \\
\hline Moderate & $26(53.1 \%)$ & $13(40.6 \%)$ & \\
\hline Mild & $10(20.4 \%)$ & $1(3.1 \%)$ & $0.0022^{\mathrm{d}, \mathrm{f}}$ \\
\hline Time of disease evolution (days) & $66.2 \pm 7.1$ & $135.0 \pm 23.4$ & $0.0004^{\mathrm{b}, \mathrm{e}}$ \\
\hline \multicolumn{4}{|l|}{ Extrapulmonary TB } \\
\hline Pleural effusion & $9(18.4 \%)$ & $7(21.9 \%)$ & \\
\hline Milliary & $4(8.2 \%)$ & $2(6.3 \%)$ & \\
\hline Other & $2(4.1 \%)$ & $0(0.0 \%)$ & $0.9255^{\mathrm{f}}$ \\
\hline
\end{tabular}

Continuous data are expressed as mean \pm SEM, and categorical data are expressed as number (percentages). HR and LR TB patients were classified according to proliferation [proliferation index: (cpm after sonicated $M t b-\mathrm{Ag}$ stimulation)/(cpm after culturing with medium)]; IFN- $\gamma$ production [fold-stimulation: $(\mathrm{ng} / \mathrm{mL}$ after sonicated $M t b-\mathrm{Ag}$ stimulation) $/(\mathrm{ng} / \mathrm{mL}$ after culturing with medium) ]; and increase in the percentage of SLAM-positive cells in response to sonicated Mtb-Ag stimulation, as previously reported (see Materials and Methods). HR, Proliferation index $\geq 4$, IFN- $\gamma$ production $>34$, increase in \% SLAM-positive cells $\geq 8$; LR proliferation index $<4$, IFN- $\gamma$ production $<34$, increase in \% SLAM-positive cells $<8$. If a patient fulfilled two of three of these criteria, the patient was assigned to that group. Radiological lesions: mild, patients with a single lobe involved and without visible cavities; moderate, patients presenting unilateral involvement of two or more lobes with cavities, if present, reaching a total diameter no greater than $4 \mathrm{~cm}$; severe, bilateral disease with massive affectation and multiple cavities. Clinical symptoms previous to hospital admission analyzed in TB patients to establish the time of disease evolution: weight loss, night sweats, symptoms of malaise or weakness, persistent fever, presence of cough, history of shortness of breath, and hemoptysis. ${ }^{\text {a }} P$ values were calculated by the Mann-Whitney $\mathrm{U}$ test for unpaired samples. ${ }^{\mathrm{b}} P$ values were calculated by the Mann-Whitney test for continuous variables. ${ }^{\mathrm{c}} P$ values were calculated by Fisher's exact test for categorical variables. ${ }^{\mathrm{d}} P<0.01$. ${ }^{\mathrm{e}} P<0.001$. ${ }^{\mathrm{f}} P$ values were calculated by the $\chi^{2}$ for trend test for categorical variables.

main population involved in the secretion of IL-17 during active TB belonged to the Th1/Th17 subset.

\section{M. tuberculosis induced Th1/Th17 lymphocytes with a memory-like phenotype in patients with active disease}

Memory T lymphocytes include different cell populations characterized by distinct homing capacity and effectors' functions [15]. To further characterize the Th1/Th17 CD4 ${ }^{+}$subset involved in the immune response to $M t b-\mathrm{Ag}$, the proportion of central and effector memory lymphocytes among CD4 ${ }^{+} \mathrm{IL}-$ $17^{+}$IFN- $\gamma^{+}$lymphocytes was investigated. We observed that after in vitro antigen stimulation, the majority of CD4 lymphocytes $(56 \% \pm 6.5)$ displayed an effector memory-like phenotype $\left(\mathrm{CCR}^{-}{ }^{-} \mathrm{CD} 45 \mathrm{RO}^{+}\right)$in TB patients (Fig. 2A), whereas in HD, $38 \% \pm 4.2$ of $\mathrm{T}$ lymphocytes displayed a central memory-like phenotype $\left(\mathrm{CCR} 7^{+} \mathrm{CD} 45 \mathrm{RO}^{+}\right.$; Fig. 2B). The proportions of cells with effector and central memory-like phenotypes detected in LR TB patients were similar to those observed in HR patients (data not shown), although LR patients displayed a lower expansion of antigen-specific cells [13].

When the effector and memory-like phenotypes on $\mathrm{Mtb}$-Agexpanded Th1/Th17 cells from TB patients were analyzed, it was observed that $\mathrm{CD} 4^{+} \mathrm{IFN}-\gamma^{+} \mathrm{IL}-17^{+} \mathrm{T}$ lymphocytes displayed central and effector memory-like phenotypes (Fig. 2A and C). Conversely, in control individuals, central memory-like $\mathrm{T}$ cells were the main producer of IL-17 and IFN- $\gamma$ (Fig. 2B and C). These results further confirm that $\mathrm{CD} 4^{+} \mathrm{IFN}-\gamma^{+} \mathrm{IL}-17^{+} \mathrm{T}$ cells are specifically induced by $\mathrm{Mtb}-\mathrm{Ag}$, as they display a memorylike phenotype (central memory or effector memory).

\section{The cytokine microenvironment influenced the expansion of IFN- $\gamma$ - and IL-17-producing lymphocytes against $M$. tuberculosis}

The cytokine milieu plays a main role during the differentiation of $\mathrm{CD}^{+}{ }^{+} \mathrm{Th}$ effectors [16]. For instance, IFN- $\gamma$ and IL-4 negatively regulate the generation of IL-17-producing cells [17, 
Figure 1. IL-17 and IFN- $\gamma$ production in response to $M t b$-Ag stimulation. (A) PBMCs from HR and LR TB patients and HD were stimulated with sonicated $M t b$-Ag for 16 h, $48 \mathrm{~h}$, and $120 \mathrm{~h}$. IL-17 and IFN- $\gamma$ levels were then determined by ELISA. Each bar represents the mean \pm SEM of IL- 17 or IFN- $\gamma$ secretion for each group ( $n=18$ for each group). Statistical differences were calculated using the nonparametric Mann-Whitney test for unpaired samples. $\# P<0.05$; \#\#P< 0.01. (B) PBMCs from HR and LR TB patients and HD were stimulated with $M t b-\mathrm{Ag}$ for 5 days, and then, IL-17 and IFN- $\gamma$ coexpression was determined by flow cytometry, first, gating on lymphocytes by light scatter and then, gating on $\mathrm{CD} 4^{+} \mathrm{T}$ cells (HR, $n=9$; LR, $n=8$; HD, $n=9$ ). A representative density plot for each group is shown. Isotype controls are shown on the right. (C) PBMCs from TB patients were stimulated with PMA + Io (PMAio) for $16 \mathrm{~h}$, and then, IL-17 and IFN- $\gamma$ coexpression was determined by flow cytometry, first, gating on lymphocytes by light scatter and then, gating on $\mathrm{CD}^{+}{ }^{+} \mathrm{T}$ cells. A representative density plot out of seven is shown. Isotype controls are shown (lower).
A

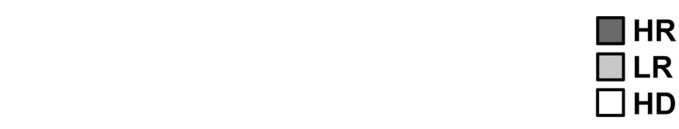

HR

$R$

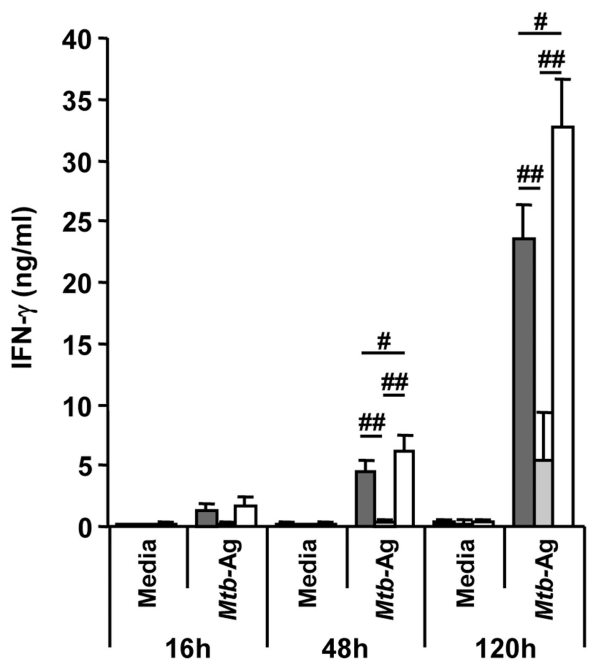

B
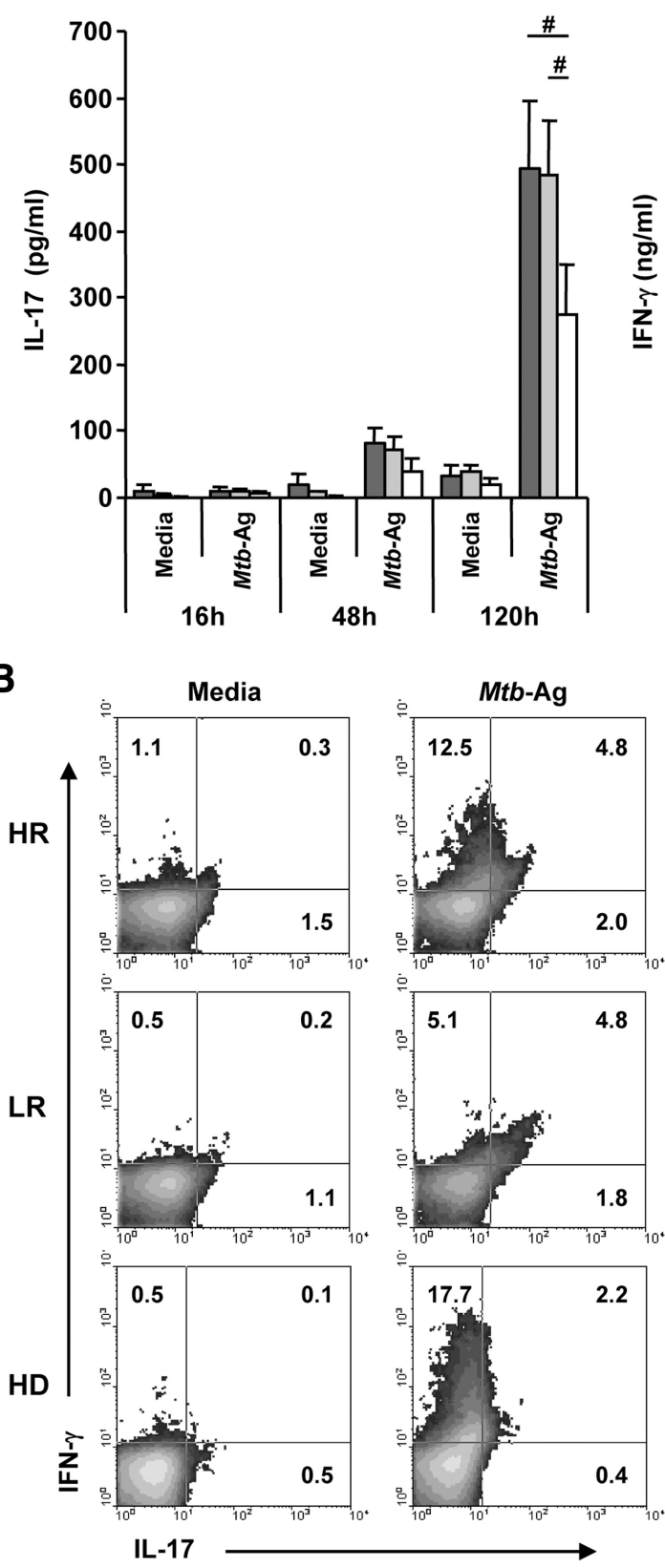

Mtb-Ag Media

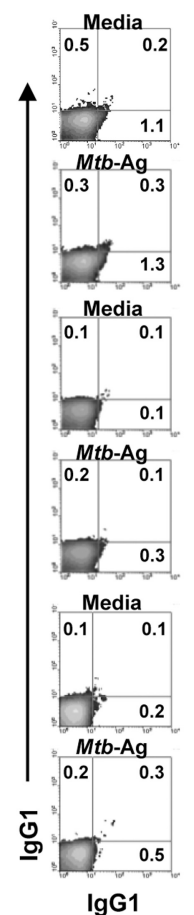

C TB

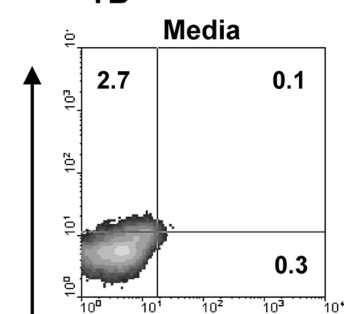

PMAio

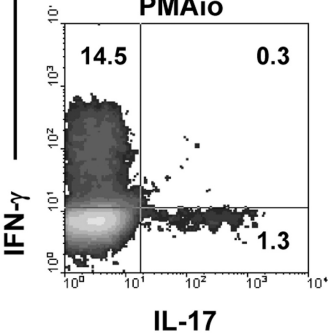

IL-17

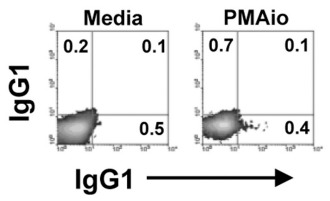

18]. In this respect, we reported previously that the addition of exogenous IL-17 significantly diminished the levels of IFN- $\gamma$ secreted by TB patients in response to $M t b-\mathrm{Ag}$ [19]. Therefore, we here analyzed whether the blockage of endogenous IFN- $\gamma$ influenced the number of IL-17-secreting lymphocytes. Surprisingly, we observed that the blocking of IFN- $\gamma$ in the presence of antigen significantly reduced the amount of IL-17 produced by both groups of TB patients, whereas it did not modify the levels of IL-17 secreted by HD (Fig. 3A). Taking into account the ample evidence demonstrating that IFN- $\gamma$ negatively regulated Th17 cells $[11,12]$, the present data were quite unexpected. In fact, blockage of IFN- $\gamma$ in cells stimulated with
PMA/Io significantly augmented the levels of IL-17 in TB patients and HD (Supplemental Fig. 2), confirming the specificity of the findings observed using Mtb-Ag. Indeed, the results indicate that $M t b$-induced IFN- $\gamma$ contributes to IL-17 secretion in patients with active disease.

To further gain insight into why IFN- $\gamma$ blockage decreased $M t b$-Ag-induced IL-17 in TB patients, the effects of IFN- $\gamma$ blockage on antigen-expanded $\mathrm{CD} 4^{+}$Th subsets were examined. As expected, blockage of endogenous IFN- $\gamma$ significantly decreased the percentage of $\mathrm{CD} 4^{+} \mathrm{IFN}-\gamma^{+} \mathrm{IL}-17^{-}$lymphocytes in the three groups of individuals studied (Fig. 3B). Moreover, anti-IFN- $\gamma$ treatment slightly increased the number of 
A

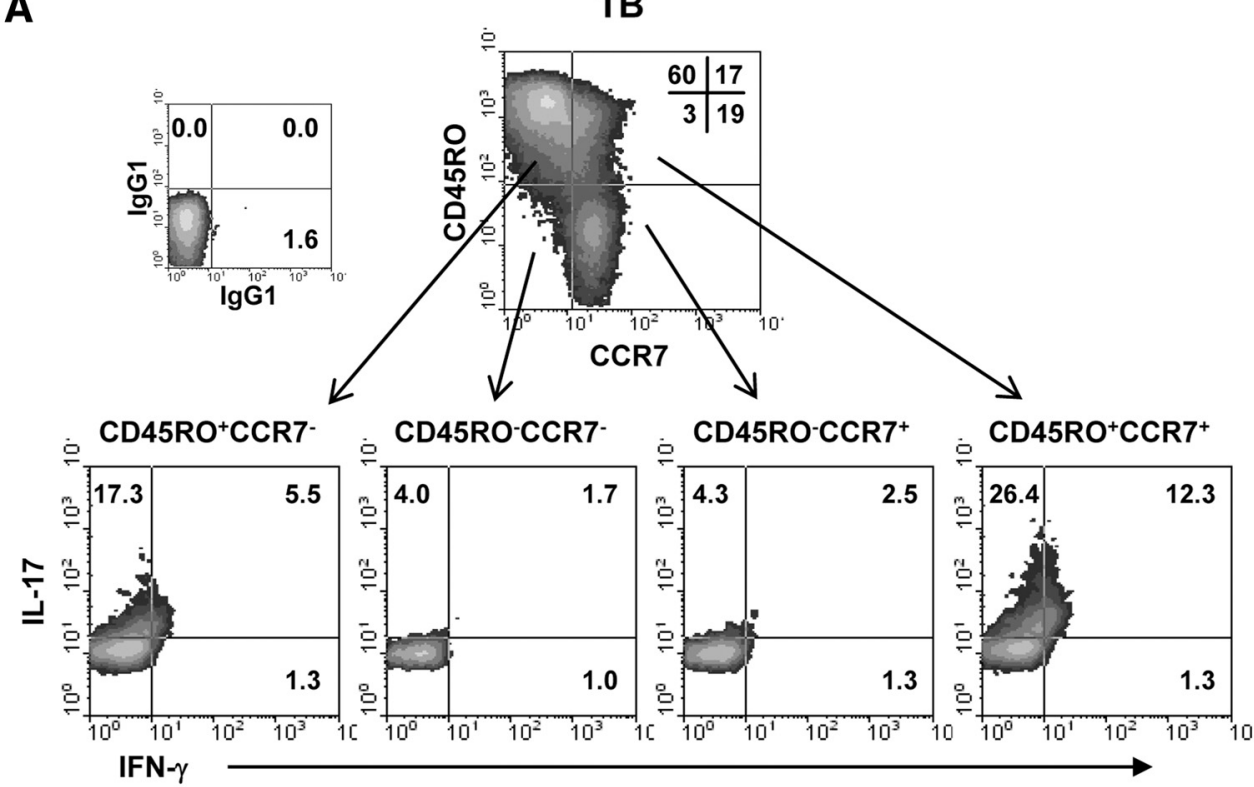

B

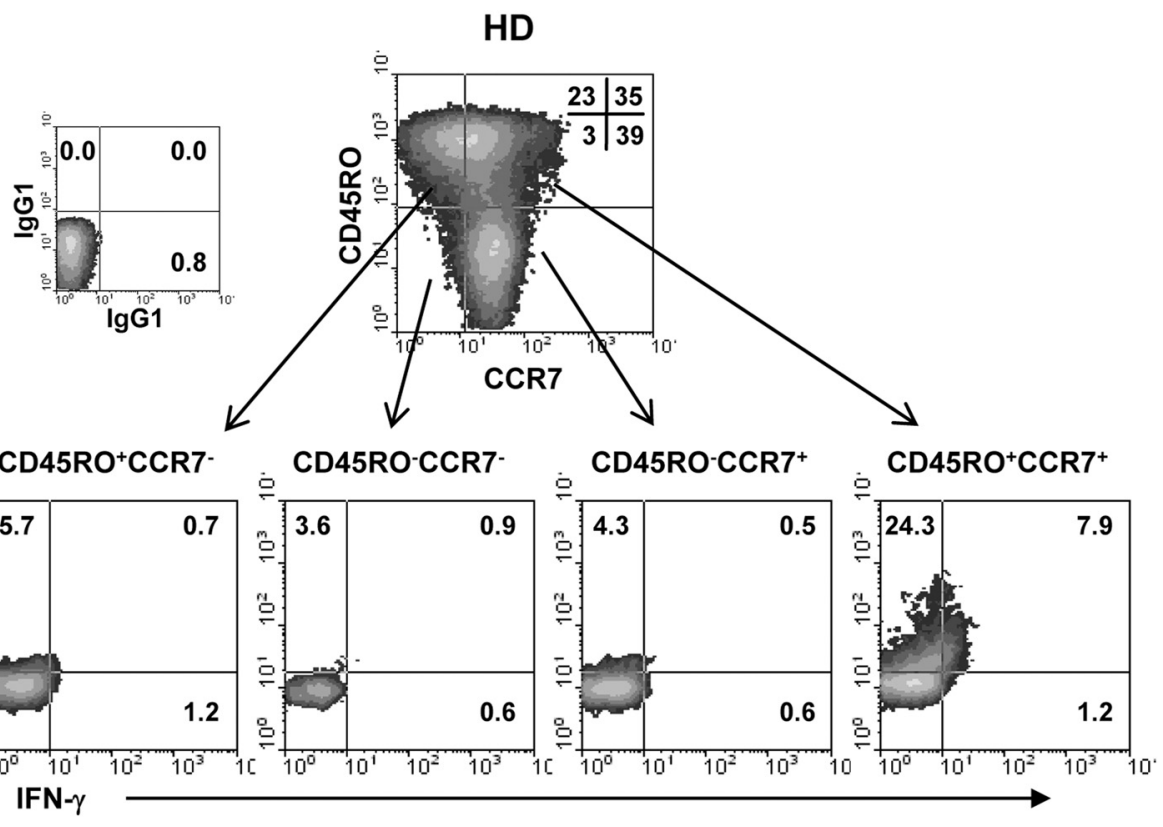

C

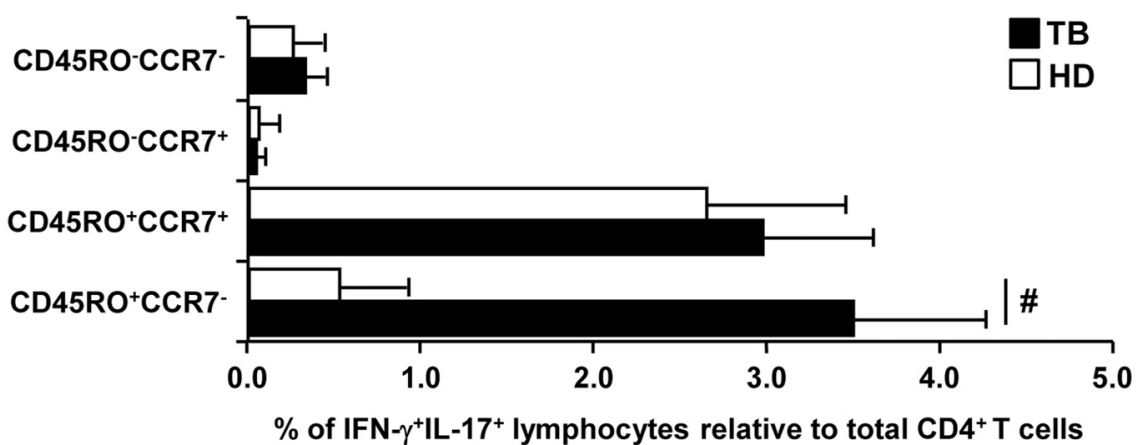

Figure 2. Phenotype profile of $\mathrm{Mtb}$-Aginduced $\mathrm{CD}^{+}$IFN- $\gamma^{+} \mathrm{IL}-17^{+}$lymphocytes. PBMCs from TB patients and HD were stimulated with sonicated $M t b$-Ag for 5 days. IL-17 and IFN- $\gamma$ coexpression was determined by flow cytometry, first, gating on lymphocytes by light scatter; then, gating on $\mathrm{CD} 4^{+} \mathrm{T}$ cells; and finally, gating according to $\mathrm{CD} 45 \mathrm{RO} / \mathrm{CCR} 7$ expression. (A) A representative dot plot of a HR patient out of seven patients analyzed is shown. (B) A representative dot plot out of seven individuals analyzed is shown for HD. Isotype controls for CD45RO and CCR7 are shown on the left. (C) Each bar represents the mean \pm SEM of the percentage of $\mathrm{CD} 4^{+}$cells that are IFN- $\gamma^{+} \mathrm{IL}-17^{+}$for each memory phenotype $\left(\mathrm{CD} 45 \mathrm{RO}^{+} \mathrm{CCR}^{+}\right.$, central memory $\mathrm{T}$ cells; CD45RO ${ }^{+} \mathrm{CCR}^{-}{ }^{-}$, effector memory $\mathrm{T}$ cells; CD45RO ${ }^{-} \mathrm{CCR}^{+}$, naïve $\mathrm{T}$ cells; or $\mathrm{CD}^{4} 5 \mathrm{RO}^{-} \mathrm{CCR}^{-}$, effector T cells).

Values were calculated as (\% of $\mathrm{CD}_{45 \mathrm{RO}^{+/}} \mathrm{CCR}^{+/-}$cells $\times \%$ of IFN$\gamma^{+}$IL- $17^{+}$cells/100). Statistical differences were calculated using the nonparametric Mann-Whitney test for unpaired samples. $\# P<0.05$. 
A

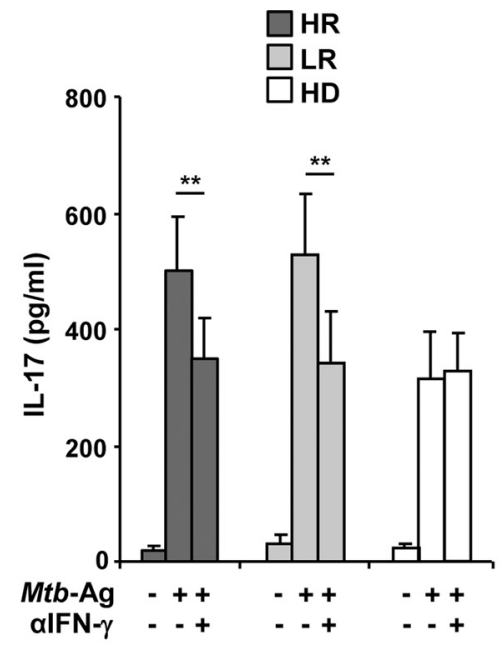

B
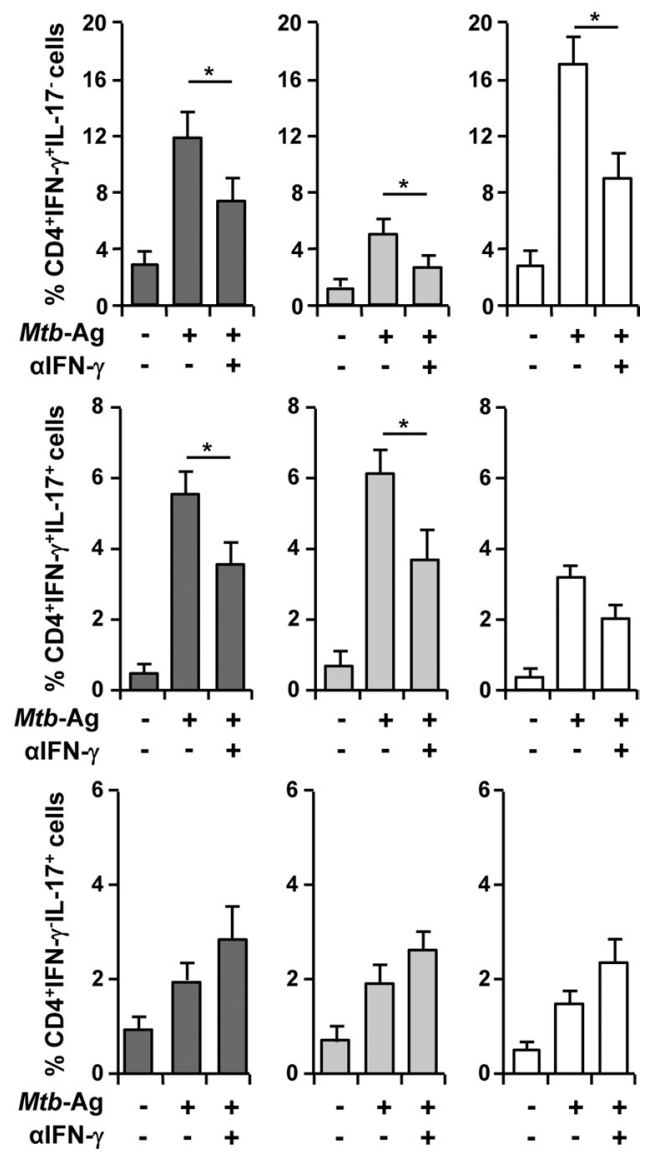

Figure 3. The expansion of Th1/Th17 lymphocytes in response to $\mathrm{Mtb}$-Ag was regulated by IFN- $\gamma$. PBMCs from HR and LR TB patients and HD were stimulated with $M t b-\mathrm{Ag}$ for 5 days in the presence or absence of $\alpha \mathrm{IFN}-\gamma \mathrm{mAb}$. The percentages of $\mathrm{CD} 4^{+} \mathrm{IFN}-\gamma^{+} \mathrm{IL}-17^{-}, \mathrm{CD} 4^{+} \mathrm{IFN}-\gamma^{-} \mathrm{IL}-17^{+}$, and $\mathrm{CD} 4^{+} \mathrm{IFN}-$ $\gamma^{+} \mathrm{IL}-17^{+}$cells and the production of IL-17 were then analyzed. (A) Each bar represents the mean \pm SEM of IL-17 secretion for each group. (B) IL-17 and IFN- $\gamma$ coexpression was determined by flow cytometry, first, gating on lymphocytes by light scatter and then, gating on $\mathrm{CD} 4^{+} \mathrm{T}$ cells. The bars represent the mean \pm SEM of the percentages of $\mathrm{CD} 4^{+} \mathrm{IFN}-\gamma^{+} \mathrm{IL}-17^{-}, \mathrm{CD} 4^{+} \mathrm{IFN}-$ $\gamma^{+} \mathrm{IL}-17^{+}$, and $\mathrm{CD} 4^{+} \mathrm{IFN}-\gamma^{-} \mathrm{IL}-17^{+}$cells for each condition. Statistical differences were calculated using the nonparametric Wilcoxon rank sum test for paired samples. $* * P<0.01 ; * P<0.05$.
$\mathrm{CD} 4^{+}$IFN- $\gamma^{-}$IL- $17^{+}$T cells (Fig. 3B). However, IFN- $\gamma$ blockage markedly diminished the percentage of $\mathrm{CD} 4^{+} \mathrm{IFN}-\gamma^{+} \mathrm{IL}-17^{+}$ (Fig. 3B). These data demonstrate that not only Th1 but also Th1/Th17 lymphocytes are positively regulated by IFN- $\gamma$ during active disease.

\section{M. tuberculosis-expanded Th1/Th17 lymphocytes were regulated by costimulatory molecules}

Several signaling proteins are known to modulate the level and pattern of cytokines produced by $\mathrm{T}$ cells upon antigen stimulation [20, 21]. In fact, as we reported previously, SLAM activation increased Th1 lymphocytes against Mtb-Ag [13], whereas PD-1 inhibited this population [22]. Although nearly $70 \%$ of $\mathrm{CD}^{+}{ }^{+} \mathrm{IFN}-\gamma^{+} \mathrm{IL}-17^{+}$cells expressed PD-1 or SLAM in TB patients, only very low levels of SLAM or PD-1 were detected on IFN- $\gamma^{-}$IL- $17^{+}$lymphocytes (Fig. 4A). The PD-1 blockage or signaling through SLAM in antigen-stimulated cells from TB patients significantly increased not only $\mathrm{CD} 4^{+}$IFN- $\gamma^{+}$IL- $17^{-}$but also CD $4^{+}$IFN- $\gamma^{+}$IL- $17^{+}$lymphocytes (Fig. 4C). The number of $\mathrm{CD} 4^{+} \mathrm{IFN}-\gamma^{-} \mathrm{IL}-17^{+}$cells was unaffected by PD-1 blockage or by SLAM activation. However, both treatments significantly increased IL-17 production against $M t b-\mathrm{Ag}$ in TB patients and HD (Fig. 4B). The present findings suggest that signaling through PD-1 inhibited the expansion of $\mathrm{CD} 4^{+}$IFN- $\gamma^{+}$IL- $17^{+}$cells, whereas activation of SLAM increased Th1/Th17 lymphocytes against the pathogen.

\section{M. tuberculosis expanded Th1/Th17 cells at the site of infection}

We next investigated the induction of Th1, Th1/Th17, and Th17 lymphocytes in TB pleural effusions. As shown in Fig. 5, M. tuberculosis strikingly enhanced the production of IL-17 and IFN- $\gamma$ by PFMCs of HR and LR TB patients (Fig. 5A). In contrast to the findings in peripheral blood, PFMCs from LR individuals secreted significantly higher levels of IL-17 compared with HR patients (Fig. 5A). In addition, PFMCs from LR patients produced markedly lower amounts of antigen-specific IFN- $\gamma$ (Fig. 5A), as we described previously [22], and the majority IL-17-producing cells was IFN- $\gamma^{+}$in both groups of patients. IFN- $\gamma$ blockage significantly reduced the percentages of $\mathrm{CD} 4^{+}$IFN- $\gamma^{+} \mathrm{IL}^{-1} 7^{-}$and $\mathrm{CD} 4^{+} \mathrm{IFN}-\gamma^{+} \mathrm{IL}-17^{+}$lymphocytes (Fig. 5B) and the production of IL-17 (Fig. 5C). Besides, PD-1 blockage or SLAM activation significantly increased the secretion of IL-17 by PFMCs (Fig. 5D). It is plausible that at the site of infection, M. tuberculosis expanded and regulated $\mathrm{CD} 4^{+}$IFN$\gamma^{+} \mathrm{IL}-17^{+}$lymphocytes in the same way as in peripheral blood.

The proportion of IL-17-secreting lymphocytes induced by $M t b-\mathrm{Ag}$ was inversely correlated with IFN- $\gamma$ production against the pathogen

The subtle balance between Th1 and Th17 responses seems to be critical in defining the outcome of $M$. tuberculosis infection [9]. We next evaluated the proportion of Th1, Th17, and Th1/Th17 lymphocytes expanded by Mtb-Ag. As shown in Fig. 6, striking differences in the proportions of $\mathrm{CD} 4^{+} \mathrm{Th}$ subsets were detected among the three groups of individuals. Indeed, whereas HD displayed the highest ratios of $\mathrm{CD} 4^{+} \mathrm{IFN}-$ 
A CD4 $^{+}$ CD4 ${ }^{+}$IFN- $\gamma^{+}$IL-17

CD4 ${ }^{+}$IFN- $\gamma^{+}$IL-17 ${ }^{+}$

CD4+IFN- $\gamma^{-I_{L}-17^{+}}$
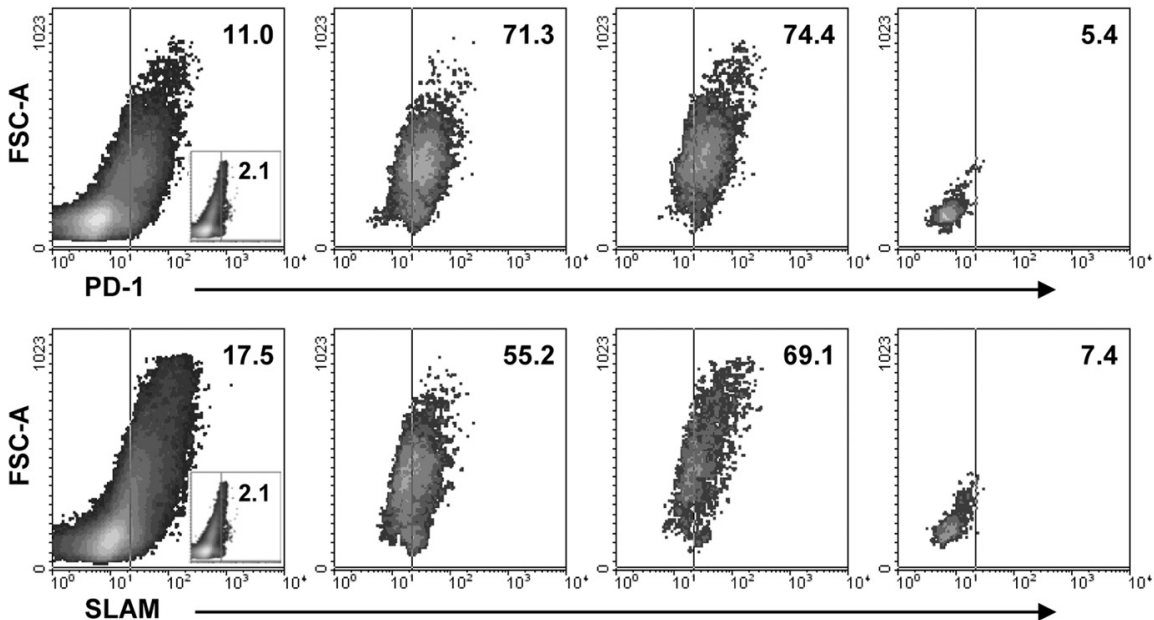

B

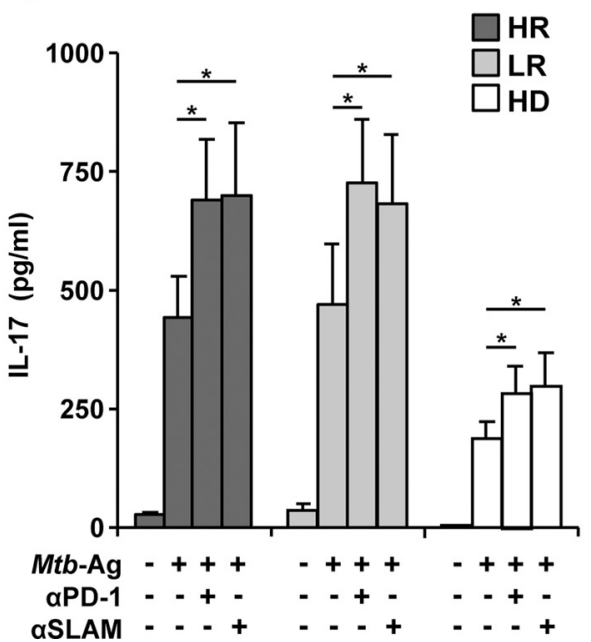

C

CD4+IFN- $\gamma^{+}$IL-17 $\triangle \mathrm{CD} 4^{+} \mathrm{IFN}-\gamma^{+} \mathrm{IL}-17^{+}$ D CD4 ${ }^{+}$IFN- $\gamma^{-}$IL-17 ${ }^{+}$

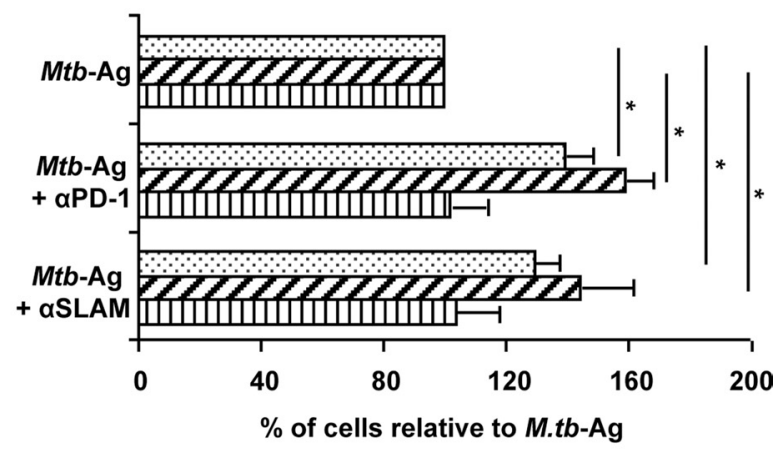

Figure 4. Expression and function of costimulatory molecules on $\mathrm{CD}^{+}{ }^{+} \mathrm{IFN}-\gamma^{+} \mathrm{IL}_{-17} 7^{-}$, $\mathrm{CD}^{+}{ }^{+} \mathrm{IFN}-\gamma^{-} \mathrm{IL}-17^{+}$, and CD4 ${ }^{+}$IFN- $\gamma^{+} \mathrm{IL}_{-1} 17^{+}$T cells from TB patients. (A) PBMCs from HR TB patients were stimulated with $M t b-\mathrm{Ag}$, and after 5 days, IL-17 and IFN- $\gamma$ coexpression in PD-1 ${ }^{+}$(upper) or $\mathrm{SLAM}^{+}$(lower) cells was determined by flow cytometry, first, gating on lymphocytes by light scatter; then, gating on $\mathrm{CD} 4^{+} \mathrm{T}$ cells; and finally, gating on $\mathrm{CD} 4^{+}$IFN- $\gamma^{+} \mathrm{IL}_{-1} 7^{-}, \mathrm{CD} 4^{+}$IFN$\gamma^{+} \mathrm{IL}-17^{+}$, or $\mathrm{CD} 4^{+} \mathrm{IFN}-\gamma^{-} \mathrm{IL}-$ $17^{+}$cells. A representative density plot for HR patients analyzed is shown. FSC-A, Forward-scatter-area. (B and C) PBMCs from HR patients were stimulated with $M t b-\mathrm{Ag}$ in the presence or absence of blocking $\alpha \mathrm{PD}-1 \mathrm{mAb}$ or agonistic $\alpha$ SLAM mAb. After 5 days of culture, IL-17 production was determined by ELISA (B), and intracellular IL-17 and IFN- $\gamma$ coexpression was determined by flow cytometry $(\mathrm{C})$, first, gating on lymphocytes by light scatter and then, gating on $\mathrm{CD} 4^{+} \mathrm{T}$ cells. (C) Each bar represents the mean \pm sEM of the percentage of cells and was calculated as: $\left(\% \mathrm{CD} 4^{+} \mathrm{IL}-17^{-}\right.$IFN$\gamma^{+}, \mathrm{CD} 4^{+} \mathrm{IL}-17^{+} \mathrm{IFN}-\gamma^{+}$, or $\mathrm{CD} 4^{+} \mathrm{IL}-17^{+} \mathrm{IFN}-\gamma^{-} \mathrm{Mtb}+$ $\alpha$ PD-1 or $M t b-\alpha$ SLAM-stimulated cells $) /\left(\% \mathrm{CD} 4^{+} \mathrm{IL}-\right.$ $17^{-} \mathrm{IFN}-\gamma^{+}, \mathrm{CD} 4^{+} \mathrm{IL}-17^{+} \mathrm{IFN}-\gamma^{+}$

or $\mathrm{CD} 4^{+} \mathrm{IL}-17^{+} \mathrm{IFN}-\gamma^{-}$Mtb-stimulated cells $) \times 100$ ( $n=8$ for all groups). Statistical differences were calculated using the nonparametric Wilcoxon rank sum test for paired samples. ${ }^{*} P<0.05$.

$\gamma^{+} \mathrm{IL}-17^{-}$cells, HR presented an intermediate proportion, and LR individuals showed the lowest ratios of $\mathrm{CD} 4^{+} \mathrm{IFN}-\gamma^{+} \mathrm{IL}-17^{-}$ lymphocytes (Fig. 6A). On the other hand, LR patients exhibited the highest proportion of $\mathrm{CD} 4^{+} \mathrm{IFN}-\gamma^{-} \mathrm{IL}-17^{+}$cells compared with the other groups. Furthermore, the highest ratio of $\mathrm{CD} 4{ }^{+} \mathrm{IFN}-\gamma^{+} \mathrm{IL}-17^{+}$cells was found in LR patients, intermediate proportions were detected in HR patients, and the lowest ratio of those lymphocytes was measured in HD (Fig. 6A). Consequent to PBMCs, PFMCs from LR patients bared a superior proportion of $\mathrm{CD} 4^{+} \mathrm{IFN}-\gamma^{+} \mathrm{IL}-17^{+}$lymphocytes expanded against $M t b$-Ag as compared with HR individuals (Fig. 6B).

As the levels of $M t b$-induced IFN- $\gamma$ represented a criterion for patient classification [13], the probable correlation between the amount of IFN- $\gamma$ secreted and the proportions of each $\mathrm{CD} 4^{+}$Th subset expanded was investigated. As expected, a positive correlation between IFN- $\gamma$ levels and the ratio of $\mathrm{CD} 4^{+}$IFN- $\gamma^{+}$IL-1 $7^{-}$lymphocytes expanded by Mtb-Ag (Fig. 6C) was found. In contrast, a striking negative association was iden- tified regarding the amount of IFN- $\gamma$ secreted by each group of individuals and the proportion of IL-17-secreting lymphocytes $\left(\mathrm{CD} 4^{+}\right.$IFN- $\gamma^{+}$IL- $17^{+}$or $\mathrm{CD} 4^{+}$IFN- $\gamma^{-}$IL- $17^{+}$; Fig. 6C). Hence, the induction of IFN- $\gamma$ responses is critically required in immunity against mycobacteria [1], whereas the expansion of IL-17-secreting lymphocytes might be associated with an impaired immunity.

Clinical parameters measured in TB patients were associated with the proportion of $M t b$-Ag-expanded CD4 ${ }^{+}$IFN- $\gamma^{+}$IL-17 ${ }^{+}$lymphocytes

At diagnosis, TB patients display elevated absolute neutrophil and monocyte counts and low lymphocyte subset counts [23]. Accordingly, we demonstrated previously that immunological features paralleled common clinical parameters analyzed in patients with TB in Argentina: HR patients had significant higher percentages of total lymphocytes compared with LR patients; HR patients exhibited higher purified protein deriva- 


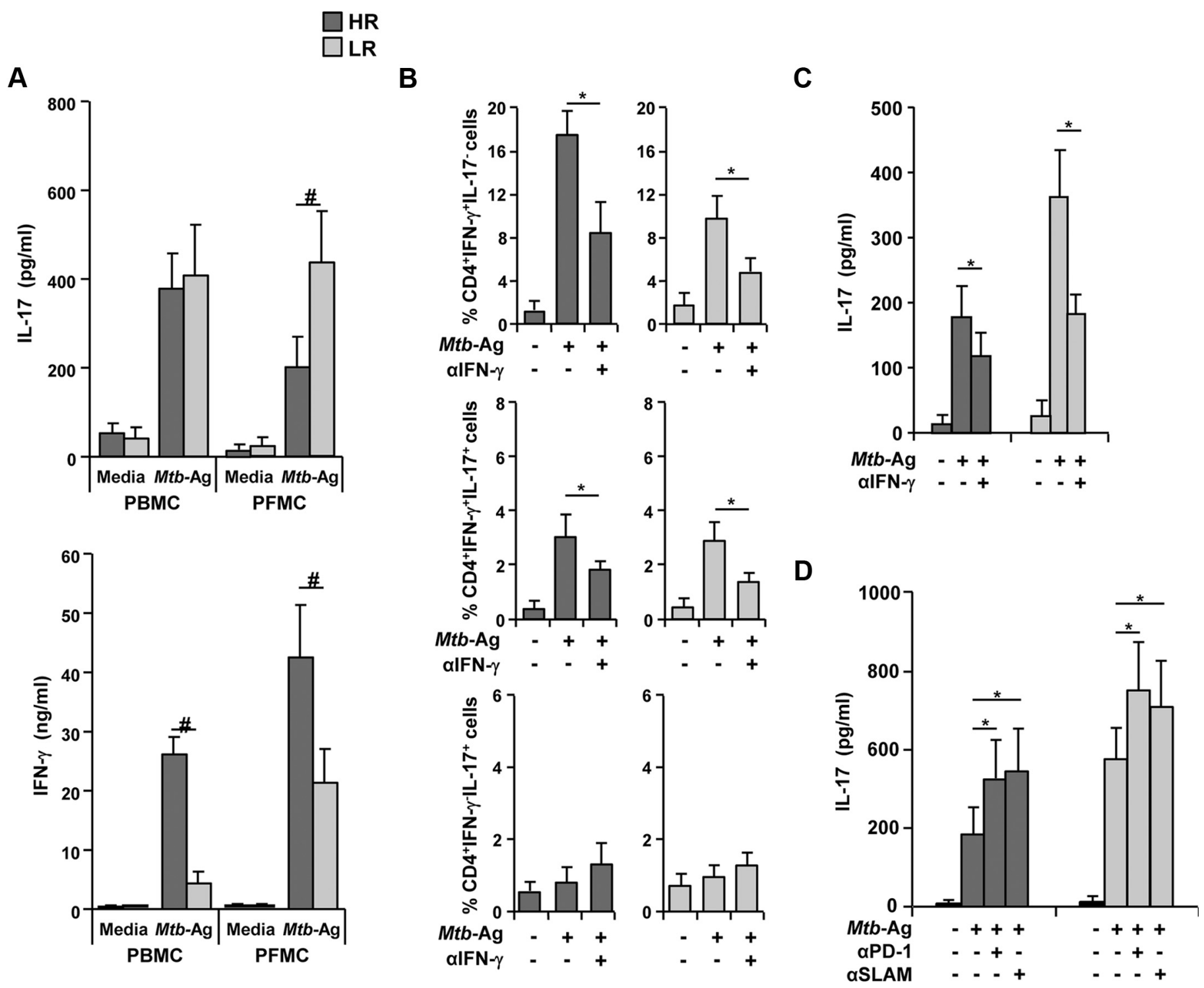

Figure 5. M. tuberculosis induced IL-17 production at the site of infection. (A) PFMCs and PBMCs from HR and LR TB patients were stimulated with $M t b-\mathrm{Ag}$ for 5 days. Afterwards, IL-17 and IFN- $\gamma$ production was determined by ELISA. Each bar represents the mean \pm sEM of IL-17 or IFN- $\gamma$ secretion for each group (HR, $n=11$; LR, $n=8$ ). (B) PFMCs from HR and LR TB patients were stimulated with $M t b$-Ag for 5 days in the presence or absence of $\alpha \mathrm{IFN}-\gamma \mathrm{mAb}$. Then, IL-17 and IFN- $\gamma$ coexpression was determined by flow cytometry, first, gating on lymphocytes by light scatter and then, gating on $\mathrm{CD} 4^{+}$T cells. Bars represent the mean \pm sEM of the percentages of $\mathrm{CD} 4^{+} \mathrm{IFN}-\gamma^{+} \mathrm{IL}-17^{-}, \mathrm{CD} 4^{+} \mathrm{IFN}-\gamma^{-} \mathrm{IL}-17^{+}$, and $\mathrm{CD} 4{ }^{+} \mathrm{IFN}-$ $\gamma^{+} \mathrm{IL}-17^{+}$cells. (C and D) PFMCs from HR and LR were stimulated with $M t b-\mathrm{Ag}$ for 5 days in the presence or absence of blocking $\alpha \mathrm{IFN}-\gamma \mathrm{mAb}$ (C) and blocking $\alpha$ PD-1 mAb or agonistic $\alpha$ SLAM mAb (D), and IL-17 production was determined by ELISA. Each bar represents the mean \pm SEM of IL-17 production for each group ( $n=12$ for all groups). Statistical differences were calculated using the nonparametric Mann-Whitney test for unpaired samples $(\# P<0.05)$ and the Wilcoxon rank sum test for paired samples $(* P<0.05)$.

tive diameters than LR patients; and LR individuals had severe pulmonary lesions, a striking loss of weight, and had been ill longer than HR individuals [13]. We further expand our previous studies by finding that LR patients exhibited significantly lower numbers of leukocytes as compared with HR individuals (Table 1). The leukocyte count was correlated directly with the proportion of $\mathrm{CD} 4^{+} \mathrm{IFN}-\gamma^{+} \mathrm{IL}-17^{-}$lymphocytes and inversely associated with the ratio of $\mathrm{CD} 4^{+} \mathrm{IFN}-\gamma^{+} \mathrm{IL}-17^{+}$cells (Fig. 7A). Furthermore, higher proportions of CD $4^{+}$IFN- $\gamma^{+}$IL$17^{+}$cells were directly associated with longer times of disease evolution, whereas elevated ratios of $\mathrm{CD} 4^{+} \mathrm{IFN}-\gamma^{+} \mathrm{IL}-17^{-}$were correlated with shorter length of disease progress (Fig. 7B). In fact, the presence of higher proportions of CD $4^{+}$IFN- $\gamma^{+}$IL- $17^{+}$ lymphocytes was correlated directly with more extensive lung affectation and a higher number of pulmonary lesions (Fig. $7 \mathrm{C}$ ), but no association between the ratio of $\mathrm{CD} 4^{+}$IFN- $\gamma^{-}$IL$17^{+}$cells and the clinical parameters investigated was found (Fig. 7). These findings demonstrate that the proportion of $\mathrm{CD} 4^{+}$IFN- $\gamma^{+}$IL- $17^{+}$cells was elevated in patients who exhibit weak cell-mediated immunity against $M$. tuberculosis. Further- 
A

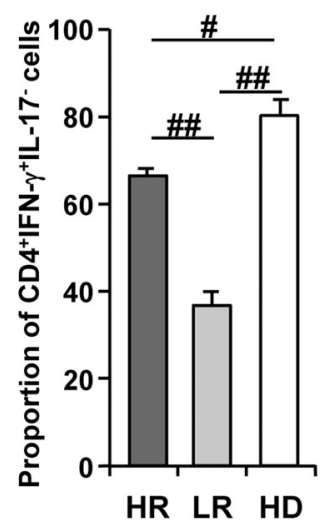

B

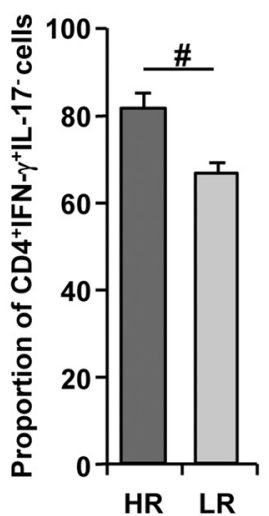

C

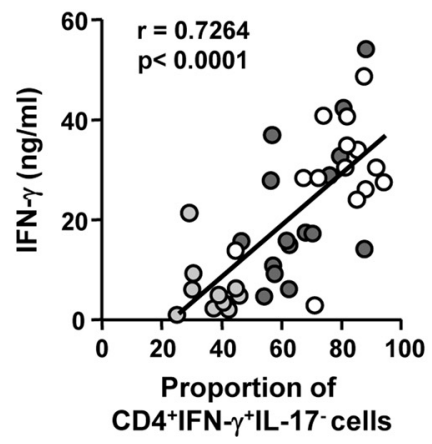

PBMC

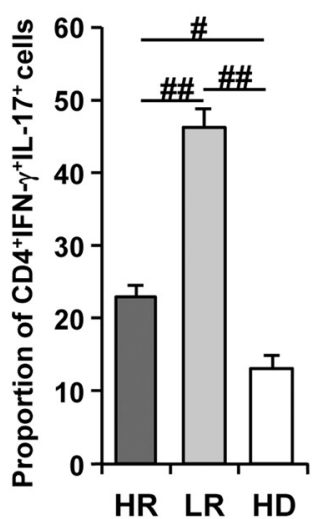

PFMC
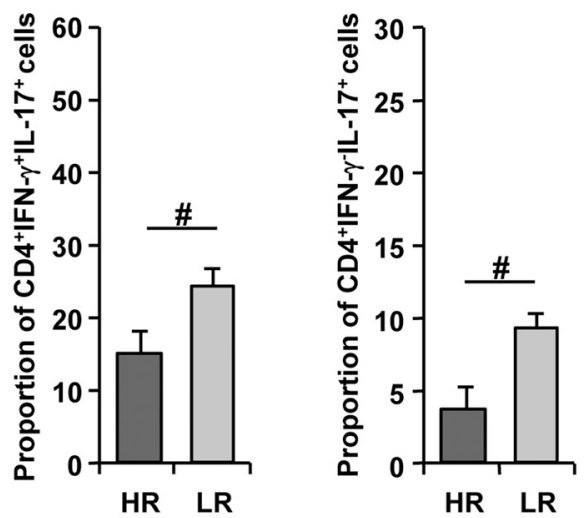

Figure 6. $M t b$-Ag differentially expanded $\mathrm{CD}^{+}{ }^{+} \mathrm{IFN}-\gamma^{+} \mathrm{IL}_{1} 17^{-}$, $\mathrm{CD} 4^{+} \mathrm{IFN}-\gamma^{-} \mathrm{IL}-17^{+}$, and CD4 ${ }^{+}$IFN- $\gamma^{+}$IL- $7^{+}$lymphocytes. PBMCs (A) and PFMCs (B) from HR and LR TB patients and PBMCs (A) from HD were stimulated with $M t b-\mathrm{Ag}$ for 5 days. Afterwards, IL-17 and IFN- $\gamma$ coexpression was determined by flow cytometry, first, gating on lymphocytes by light scatter and then, gating on $\mathrm{CD} 4^{+} \mathrm{T}$ cells. The proportions of Th1, Th1/Th17, and Th17 cells induced by $M t b-\mathrm{Ag}$ were calculated as the ratio of IFN$\gamma^{+} \mathrm{IL}-17^{-}$(Th1), IFN- $\gamma^{+} \mathrm{IL}-17^{+}$ (Th1/Th17), or IFN- $\gamma^{-} \mathrm{IL}-17^{+}$ (Th17) cells relative to the total number of cytokine-producing cells $\left(100 \%\right.$ of cells $=\mathrm{IFN}-\gamma^{+} \mathrm{IL}-$ $17^{-}+\mathrm{IFN}-\gamma^{+} \mathrm{IL}-17^{+}+\mathrm{IFN}-\gamma^{-} \mathrm{IL}-$ $17^{+)}$. Statistical differences were calculated using the nonparametric Mann-Whitney test for unpaired samples. \#P<0.05; \#P< 0.01. (C) Correlation between IFN- $\gamma$ production and the proportion of Th1, Th1/Th17, or Th17 lymphocytes. Values are expressed as IFN- $\gamma$ production (IFN- $\gamma$ produced by $M t b$-Ag-stimulated cell-

OHR $s-$ IFN- $\gamma$ produced by cells cul-
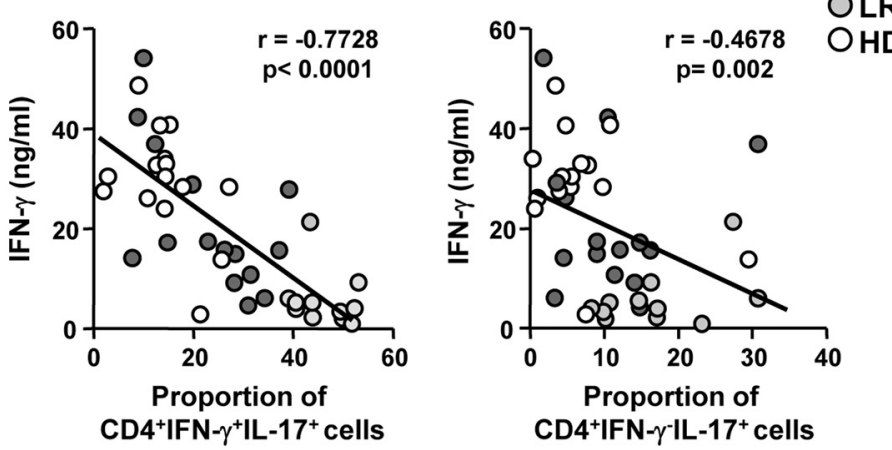

tured with media) versus the proportion of Th1, Th1/Th17, or Th17 cells for each group of individuals. Correlation factor $(r)$ and $P$ values were calculated using the nonparametric Spearman correlation test. Proportions were calculated as described in A. HR, $n=$ 15 ; LR, $n=11$. more, $\mathrm{CD} 4^{+} \mathrm{IFN}-\gamma^{+} \mathrm{IL}-17^{+}$lymphocyte ratio was directly related to clinical parameters, indicating disease severity.

\section{DISCUSSION}

IFN- $\gamma$-producing Th1 cells are essential to control mycobacterial replication [24-26]. Indeed, reduced IFN- $\gamma$ production is a marker of severe disease [27]. Hence, we previously identified HR and LR TB patients based on their T cell responses to M. tuberculosis [13]. In spite of that, Th1 cells alone do not explain the resistance/susceptibility to infection and disease [28], suggesting that other cytokines might be required during the immune regulation of TB [6, 29]. Besides Th1 lymphocytes, Th17 cells have also been associated with $M$. tuberculosis infection $[6,10]$. IL-17-producing lymphocytes constitute a significant proportion of $M$. tuberculosis-activated cells in PBMCs of healthy tuberculin reactors [6]. We have demonstrated that the number of Th17 cells was increased significantly in TB patients compared with BCG-vaccinated controls [19]. Furthermore, we have shown previously that IL-17 inhibited IFN- $\gamma$ production during human TB by decreasing the expression and function of stimulatory signaling proteins [19]. As a result of the fact that IFN- $\gamma$ and Th17 cells possess antagonistic effects $[11,12,19]$, we speculate that the increase in 
A

Figure 7. The ratio of Th1Th1/Th17-Th17 lymphocytes correlated with clinical parameters in TB patients. PBMCs from HR and LR TB patients were stimulated with $M t b-\mathrm{Ag}$ for 5 days. Afterwards, IL-17 and IFN- $\gamma$ coexpression was determined by flow cytometry, first, gating on lymphocytes by light scatter and then, gating on $\mathrm{CD} 4^{+} \mathrm{T}$ cells. (A) Each dot represents the proportion of $\mathrm{CD} 4^{+} \mathrm{IFN}-\gamma^{+} \mathrm{IL}-17^{-}, \mathrm{CD} 4^{+}$IFN$\gamma^{-} \mathrm{IL}-17^{+}$, and $\mathrm{CD} 4^{+} \mathrm{IFN}-\gamma^{+} \mathrm{IL}-$ $17^{+}$cells versus the number of leukocytes $\left(10^{3}\right.$ cells $\left./ \mathrm{mm}^{3}\right)$ for each patient analyzed. (B)

Each dot represents the proportion of $\mathrm{CD} 4^{+} \mathrm{IFN}-\gamma^{+} \mathrm{IL}_{-1} 7^{-}$, $\mathrm{CD} 4^{+} \mathrm{IFN}-\gamma^{-} \mathrm{IL}-17^{+}$, and $\mathrm{CD} 4^{+} \mathrm{IFN}-\gamma^{+} \mathrm{IL}-17^{+}$cells versus the time of disease evolution (days) for each patient analyzed. (A and B) Correlation factor (r) and $P$ were calculated by the nonparametric Spearman correlation test. (C) Each dot represents the proportion of Th1, Th1/Th17, or Th17 cells versus the severity of the radiological lesions (severe, moderate, and mild; see Table 1) for each patient analyzed. Statistical differences were calculated using the ANOVA test. (A-C) Proportions were calculated as described in Fig. 6. HR, $n=15$; LR, $n=11$.
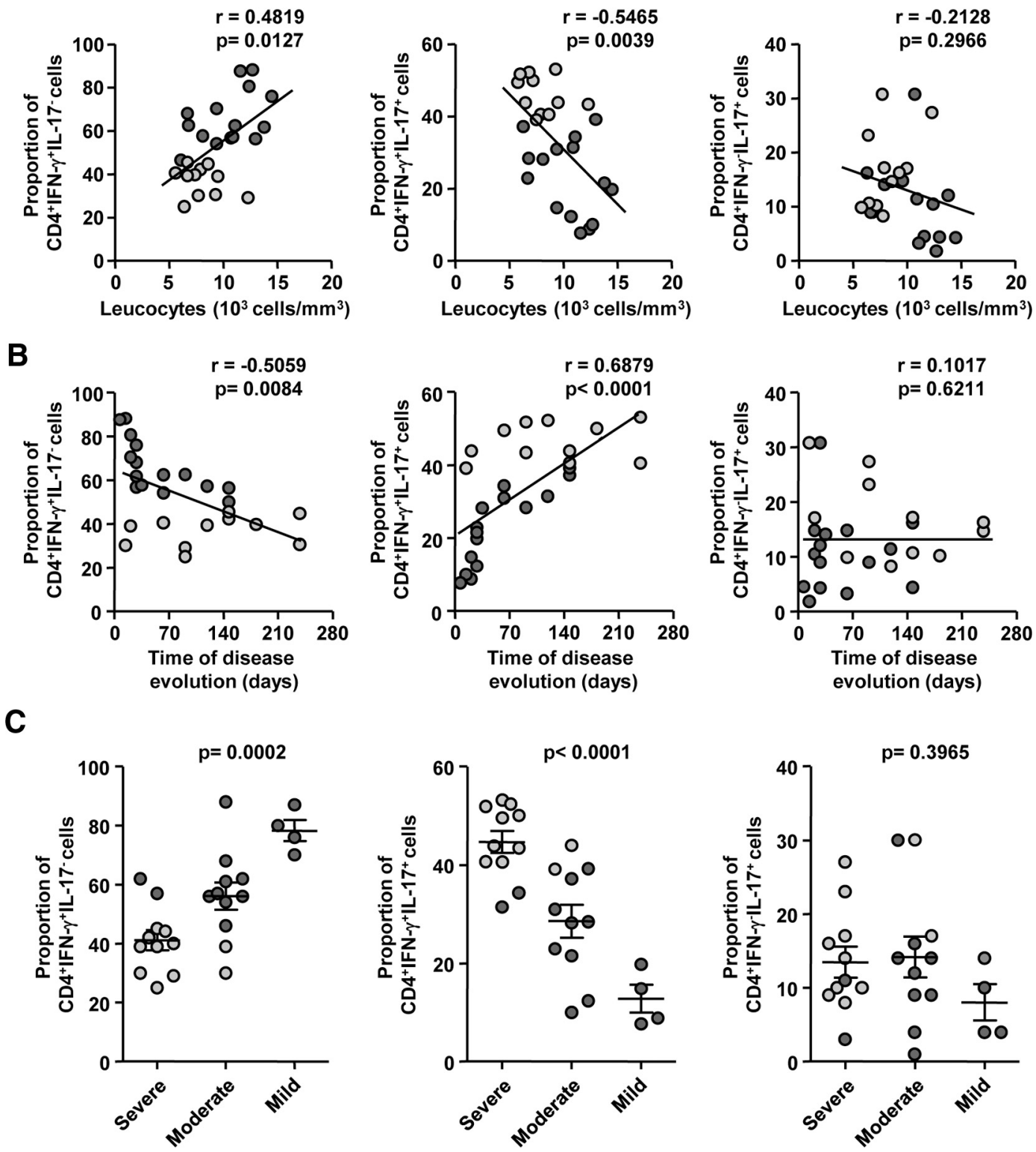

tion of lymphocytes that combines the proinflammatory potential of Th1 and Th17 cells [31-33]. Herein and to our knowledge, we demonstrated for the first time, that $\mathrm{CD} 4^{+}$IFN$\gamma^{+}$IL- $17^{+}$lymphocytes were expanded during human active TB in correlation with the disease severity.

As mentioned already in Results, IFN- $\gamma$ blockage markedly diminished the IL-17 secretion induced upon antigen stimulation, a decrease related to a significant down-regulation of IFN- $\gamma^{+}$IL $17^{+}$lymphocytes. In fact, anti-IFN- $\gamma$ treatment only slightly augmented IFN- $\gamma^{-}$IL- $17^{+} \mathrm{T}$ cells, without modifying the resulting IL-17 reduction in the cellular milieu. In contrast, the overall effect of the blockage of IFN- $\gamma$ on the production of IL-17 in control individuals was not significant. The 
regulation of IFN- $\gamma$ on IL-17 secretion by TB patients was detected after stimulation with the specific antigen but not with a polyclonal stimulus, indicating that $M$. tuberculosis-induced IFN- $\gamma$ participated in the induction of Th1/Th17 cells during active disease. In fact, costimulation through molecules that modulate IFN- $\gamma$ responses in TB $[13,22]$ also regulated IL-17 production during active disease.

As we reported previously, common clinical parameters analyzed in patients with active TB in Argentina paralleled immunological parameters studied in those individuals, allowing the classification of patients in HR and LR individuals [13]. Our present results extend those findings, demonstrating a positive association between two clinical parameters (time of disease evolution and pulmonary lesions) and the proportion of $\mathrm{CD} 4{ }^{+} \mathrm{IFN}-\gamma^{+} \mathrm{IL}-17^{+}$lymphocytes expanded in response to $\mathrm{Mtb}$ Ag. In fact, LR TB patients, whose severity parameters were described above, showed higher ratios of Th1/Th17 cells in pleural fluids and peripheral blood compared with HR patients. Therefore, our findings provide evidence that the proportion of $\mathrm{CD} 4^{+} \mathrm{IFN}-\gamma^{+} \mathrm{IL}-17^{+}$lymphocytes in patients with active TB might be associated with the severity of the disease.

An important aspect of this report was to evaluate the induction of Th1/Th17 lymphocytes in pleural fluids from TB patients. Our results in PFMCs confirmed that the majority of IL-17-producing lymphocytes against $M t b-\mathrm{Ag}$ also coproduced IFN- $\gamma$ and displayed elevated levels of SLAM and PD-1. Furthermore, patients with weak immunity to $M$. tuberculosis presented the highest proportions of IFN- $\gamma^{+}$IL $-17^{+}$T lymphocytes at the site of infection, strongly supporting the fact that this subset of $\mathrm{CD}^{+} \mathrm{T}$ cells might play a potential, detrimental role during M. tuberculosis infection. In contrast to us, Chen et al. [34] did not detect IFN- $\gamma^{+}$IL- $17^{+}$T cells in patients with active TB and reported that the magnitude of the Th17 response was associated with the clinical outcome of M. tuberculosis infection. Nevertheless, the discrepancies may be attributed to differences in the experimental design and/or stimulation protocols used. Basically, Chen et al. [34] stimulated fresh blood and PBMCs/PFMCs with PMA/ionomicyn for $6 \mathrm{~h}$ or PBMCs/PFMCs with H37Rv lysate during 3 days. By performing those protocols, the authors reported significantly lower frequency of nonspecific Th17 responses in TB patients as compared with HD and suggested that those nonspecific responses might involve Th17 cells derived from naïve $\mathrm{CD} 4^{+} \mathrm{T}$ cells [34]. Regarding the stimulation with the specific antigen, the authors obtained undetectable Th17 cell responses [34]. In the present work, we investigated the frequency of antigenspecific, IL-17-secreting lymphocytes in PBMCs and PFMCs from TB patients. As demonstrated in Fig. 1, significant levels of IL-17 were detected at 5 days of stimulation with sonicated H37Rv but not earlier. Furthermore, we showed that M. tuberculosis induced significant secretion of IL-17 from CD $4{ }^{+}$IFN$\gamma^{+} \mathrm{IL}-17^{+} \mathrm{T}$ cells and that these lymphocytes displayed a memory-like phenotype.

It is worth noticing that the majority of our results obtained in peripheral blood of TB patients was replicated in PFMCs of the same individuals, which strongly suggests that the determinations in PBMCs reflect what is occurring at the site of infection. Taken together, the analysis of Th1-Th1/Th17-Th17 lym- phocyte ratios in peripheral blood might be used as an indicator of the clinical manifestations of the disease.

In conclusion, we demonstrated that during human $\mathrm{TB}$, IL-17 was secreted mainly by Th1/Th17 cells, a population of $\mathrm{CD} 4{ }^{+} \mathrm{IFN}-\gamma^{+} \mathrm{IL}-17^{+}$lymphocytes regulated by IFN- $\gamma$ and present in proportions directly associated with the time of disease evolution and pulmonary lesions. The association of the ratio of Mtb-expanded Th1/Th17 cells with disease severity suggests that these lymphocytes might comprise a potentially pathogenic population during active TB. In this line, although blocking and agonistic mAb have shown promise for their use in therapies for chronic viral diseases and malignancies [35], caution should be taken in designing ways to promote Th1 responses during chronic $M$. tuberculosis infection, as the production of IFN- $\gamma$ could also result in an inappropriate expansion of Th1/Th17 lymphocytes and pathology. According to our present findings, although IFN- $\gamma$ is required to achieve a protective response to $M$. tuberculosis, therapeutically, addition of exogenous IFN- $\gamma$ would not be a solution to achieve a strong cell-mediated immunity response to M. tuberculosis. It is plausible that the balance between Th1 and Th1/Th17 cells, with higher numbers of Th1 over Th1/Th17 lymphocytes, would contribute to a protective response against $M$. tuberculosis. Further studies are required to elucidate the pathogenicity of Th1/Th17 lymphocytes during human active TB.

\section{AUTHORSHIP}

J.O.J., V.P., and V.E.G. conceived of and designed the experiments. J.O.J., V.P., I.B.A., and A.I.R. performed the experiments. J.O.J. and V.E.G. analyzed the data. J.O.J., A.I.R., N.L.T., R.M.M., D. Palmero, and H.E.C. contributed reagents/ materials/analysis tools. J.O.J., D. Peña, H.E.R., and V.E.G. wrote the paper.

\section{ACKNOWLEDGMENTS}

This investigation received financial support from the National Institutes of Health, National Institute of Allergy and Infectious Diseases (R01 AI079007 to V.E.G), Agencia Nacional de Promoción Científica y Tecnológica (PICT 01,384 to V.E.G.; PICT 02,331 to H.E.C), and the University of Buenos Aires (UBACyT X087 and UBACyT 20020100100221 to V.E.G.). J.O.J., I.B.A., A.I.R., and N.L.T. are fellows of CONICET (Argentina). D. Peña is a fellow from ANPCyT (Argentina). V.P., H.E.C., and V.E.G. are members of the Researcher Career of CONICET (Argentina). We thank Drs. Peter Barnes and Buka Samten for insightful discussions. We also thank Dr. Catalina Feledi for technical support.

\section{REFERENCES}

1. Cooper, A. M., Dalton, D. K., Stewart, T. A., Griffin, J. P., Russell, D. G., Orme, I. M. (1993) Disseminated tuberculosis in interferon $\gamma$ gene-disrupted mice. J. Exp. Med. 178, 2243-2247.

2. Flynn, J. L., Chan, J., Triebold, K. J., Dalton, D. K., Stewart, T. A., Bloom, B. R. (1993) An essential role for interferon gamma in resistance to Mycobacterium tuberculosis infection. J. Exp. Med. 178, 2249-2254

3. Newport, M. J., Huxley, C. M., Huston, S., Hawrylowicz, C. M., Oostra, B. A., Williamson, R., Levin, M. (1996) A mutation in the interferon- $\gamma$ - 
receptor gene and susceptibility to mycobacterial infection. N. Engl. J. Med. 335, 1941-1949.

4. Holland, S. M. (2007) Interferon $\gamma$, IL-12, IL-12R and STAT-1 immunodeficiency diseases: disorders of the interface of innate and adaptive immunity. Immunol. Res. 38, 342-346.

5. Flynn, J. L. (2006) Lessons from experimental Mycobacterium tuberculosis infections. Microbes Infect. 8, 1179-1188.

6. Scriba, T. J., Kalsdorf, B., Abrahams, D. A., Isaacs, F., Hofmeister, J., Black, G., Hassan, H. Y., Wilkinson, R. J., Walzl, G., Gelderbloem, S. J., Mahomed, H., Hussey, G. D., Hanekom, W. A. (2008) Distinct, specific IL-17- and IL-22-producing CD4+ T cell subsets contribute to the human anti-mycobacterial immune response. J. Immunol. 180, 1962-1970.

7. Cooper, A. M. (2010) Editorial: be careful what you ask for: is the presence of IL-17 indicative of immunity? J. Leukoc. Biol. 88, 221-223.

8. Lazar-Molnar, E., Chen, B., Sweeney, K. A., Wang, E. J., Liu, W., Lin, J., Porcelli, S. A., Almo, S. C., Nathenson, S. G., Jacobs Jr., W. R. (2010) Programmed death-1 (PD-1)-deficient mice are extraordinarily sensitive to tuberculosis. Proc. Natl. Acad. Sci. USA 107, 13402-13407.

9. Torrado, E., Cooper, A. M. (2010) IL-17 and Th17 cells in tuberculosis. Cytokine Growth Factor Rev. 21, 455-462.

10. Khader, S. A., Cooper, A. M. (2008) IL-23 and IL-17 in tuberculosis. Cy tokine 41, 79-83.

11. Mills, K. H. (2008) Induction, function and regulation of IL-17-producing T cells. Eur. J. Immunol. 38, 2636-2649.

12. Bettelli, E., Carrier, Y., Gao, W., Korn, T., Strom, T. B., Oukka, M., Weiner, H. L., Kuchroo, V. K. (2006) Reciprocal developmental pathways for the generation of pathogenic effector TH17 and regulatory T cells. Nature 441, 235-238.

13. Pasquinelli, V., Quiroga, M. F., Martinez, G. J., Zorrilla, L. C., Musella, R. M., Bracco, M. M., Belmonte, L., Malbran, A, Fainboim, L., Sieling, P. A., Garcia, V. E. (2004) Expression of signaling lymphocytic activation molecule-associated protein interrupts IFN- $\gamma$ production in human tuberculosis. J. Immunol. 172, 1177-1185.

14. Mahuad, C., Bay, M. L., Farroni, M. A., Bozza, V., Del Rey, A., Besedovsky, H., Bottasso, O. A. (2004) Cortisol and dehydroepiandrosterone affect the response of peripheral blood mononuclear cells to mycobacterial antigens during tuberculosis. Scand. J. Immunol. 60, 639-646.

15. Sallusto, F., Geginat, J., Lanzavecchia, A. (2004) Central memory and effector memory $\mathrm{T}$ cell subsets: function, generation, and maintenance. Annu. Rev. Immunol. 22, 745-763.

16. Boniface, K., Blumenschein, W. M., Brovont-Porth, K., McGeachy, M. J., Basham, B., Desai, B., Pierce, R., McClanahan, T. K., Sadekova, S., de Waal Malefyt, R. (2010) Human Th17 cells comprise heterogeneous subsets including IFN- $\gamma$-producing cells with distinct properties from the Th1 lineage. J. Immunol. 185, 679-687.

17. Harrington, L. E., Hatton, R. D., Mangan, P. R., Turner, H., Murphy, T. L., Murphy, K. M., Weaver, C. T. (2005) Interleukin 17-producing $\mathrm{CD} 4+$ effector $\mathrm{T}$ cells develop via a lineage distinct from the $\mathrm{T}$ helper type 1 and 2 lineages. Nat. Immunol. 6, 1123-1132.

18. Park, H., Li, Z., Yang, X. O., Chang, S. H., Nurieva, R., Wang, Y. H. Wang, Y., Hood, L., Zhu, Z., Tian, Q., Dong, C. (2005) A distinct lineage of CD4 T cells regulates tissue inflammation by producing interleukin 17. Nat. Immunol. 6, 1133-1141.

19. Pasquinelli, V., Townsend, J. C., Jurado, J. O., Alvarez, I. B., Quiroga, M. F., Barnes, P. F., Samten, B., Garcia, V. E. (2009) IFN- $\gamma$ production during active tuberculosis is regulated by mechanisms that involve IL-17, SLAM, and CREB. J. Infect. Dis. 199, 661-665.

20. Thompson, C. B., Allison, J. P. (1997) The emerging role of CTLA-4 as an immune attenuator. Immunity 7, 445-450.

21. Oosterwegel, M. A., Greenwald, R. J., Mandelbrot, D. A., Lorsbach, R. B., Sharpe, A. H. (1999) CTLA-4 and T cell activation. Curr. Opin. Immunol. 11, 294-300.
22. Jurado, J. O., Alvarez, I. B., Pasquinelli, V., Martinez, G. J., Quiroga, M. F., Abbate, E., Musella, R. M., Chuluyan, H. E., Garcia, V. E. (2008) Programmed death (PD)-1: PD-ligand 1/PD-ligand 2 pathway inhibits $\mathrm{T}$ cell effector functions during human tuberculosis. J. Immunol. 181, 116125

23. Veenstra, H., Baumann, R., Carroll, N. M., Lukey, P. T., Kidd, M., Beyers, N., Bolliger, C. T., van Helden, P. D., Walzl, G. (2006) Changes in leucocyte and lymphocyte subsets during tuberculosis treatment; prominence of CD3dimCD56+ natural killer T cells in fast treatment responders. Clin. Exp. Immunol. 145, 252-260.

24. Salgame, P. (2005) Host innate and Th1 responses and the bacterial factors that control Mycobacterium tuberculosis infection. Curr. Opin. Immunol. 17, 374-380.

25. Flesch, I., Kaufmann, S. H. (1987) Mycobacterial growth inhibition by interferon- $\gamma$-activated bone marrow macrophages and differential susceptibility among strains of Mycobacterium tuberculosis. J. Immunol. 138, 4408-4413.

26. Serbina, N. V., Lazarevic, V., Flynn, J. L. (2001) CD4(+) T cells are required for the development of cytotoxic CD8(+) T cells during Mycobacterium tuberculosis infection. J. Immunol. 167, 6991-7000.

27. Gong, J. H., Zhang, M., Modlin, R. L., Linsley, P. S., Iver, D., Lin, Y., Barnes, P. F. (1996) Interleukin-10 downregulates Mycobacterium tuberculosis-induced Th1 responses and CTLA-4 expression. Infect. Immun. 64, 913-918.

28. Forbes, E. K., Sander, C., Ronan, E. O., McShane, H., Hill, A. V., Beverley, P. C., Tchilian, E. Z. (2008) Multifunctional, high-level cytokineproducing Th1 cells in the lung, but not spleen, correlate with protection against Mycobacterium tuberculosis aerosol challenge in mice. J. Immunol. 181, 4955-4964.

29. Flynn, J. L., Chan, J. (2001) Immunology of tuberculosis. Annu. Rev. Immunol. 19, 93-129.

30. Kebir, H., Ifergan, I., Alvarez, J. I., Bernard, M., Poirier, J., Arbour, N., Duquette, P., Prat, A. (2009) Preferential recruitment of interferon- $\gamma$ expressing TH17 cells in multiple sclerosis. Ann. Neurol. 66, 390-402.

31. Nistala, K., Adams, S., Cambrook, H., Ursu, S., Olivito, B., de Jager, W., Evans, J. G., Cimaz, R., Bajaj-Elliott, M., Wedderburn, L. R. (2010) Th17 plasticity in human autoimmune arthritis is driven by the inflammatory environment. Proc. Natl. Acad. Sci. USA 107, 14751-14756.

32. Annunziato, F., Cosmi, L., Santarlasci, V., Maggi, L., Liotta, F., Mazzinghi, B., Parente, E., Fili, L., Ferri, S., Frosali, F., Giudici, F., Romagnani, P., Parronchi, P., Tonelli, F., Maggi, E., Romagnani, S. (2007) Phenotypic and functional features of human Th17 cells. J. Exp. Med. 204, 1849-1861.

33. Lexberg, M. H., Taubner, A., Albrecht, I., Lepenies, I., Richter, A., Kamradt, T., Radbruch, A., Chang, H. D. (2010) IFN- $\gamma$ and IL-12 synergize to convert in vivo generated Th17 into Th1/Th17 cells. Eur. J. Immunol. 40, 3017-3027.

34. Chen, X., Zhang, M., Liao, M., Graner, M. W., Wu, C., Yang, Q., Liu, H., Zhou, B. (2010) Reduced Th17 response in patients with tuberculosis correlates with IL-6R expression on CD4+ T Cells. Am. J. Respir. Crit. Care Med. 181, 734-742.

35. Alfaro, C., Murillo, O., Tirapu, I., Azpilicueta, A., Huarte, E., Arina, A., Arribillaga, L., Perez-Gracia, J. L., Bendandi, M., Prieto, J., Lasarte, J. J., Melero, I. (2006) [The immunotherapy potential of agonistic antiCD137 (4-1BB) monoclonal antibodies for malignancies and chronic viral diseases]. An. Sist. Sanit. Navar. 29, 77-96.

\section{KEY WORDS:}

tuberculosis $\cdot$ Th1/Th17 cells $\cdot$ cytokines $\cdot$ costimulation 